\title{
A world map of esophagus cancer research: a critical accounting
}

\author{
Doris Klingelhöfer ${ }^{1 *}$ (D, Yun Zhu ${ }^{2}$, Markus Braun ${ }^{1}$, Dörthe Brüggmann ${ }^{1}$, Norman Schöffel ${ }^{1}$ \\ and David A. Groneberg ${ }^{1}$
}

\begin{abstract}
Background: Esophageal cancer (EC) is one of the deadliest cancers worldwide. The contemporary strong increase of the adenocarcinomas in Western countries and the high mortality rates require the intensification of prospective multinational studies.

Methods: Therefore, this global health issue has been chosen for the bibliometric review of the global publication output. As source for meta and citation data, the Web of Science has been used and Density Equalizing Maps were applied for visualization.

Results: 17,387 articles on EC could be identified. The years with publication and citation maxima correspond to the appearance of the most prolific articles. China is the most publishing country, followed by Japan and the USA. Germany and the UK ranked 4 th and 5 th. The analysis of the ratios articles and socio-economic parameters emphasizes the leading position of the Scandinavian countries and Japan. Here, the high-income countries come out on top. The high incidence regions are mainly represented by Chinese and Japanese research. The association of the publication output and the overall research funding could be shown.

Conclusions: A strengthened international network increasingly consisting of the scientifically best positioned countries as well as more of the high incidence countries worldwide is mandatory for future research. The findings deliver scientists, clinicians and decision makers backgrounds for future decisions all over the world.
\end{abstract}

Keywords: Adenocarcinoma, Cancer epidemiology, Disease burden, Research trends, Funding, Incidence

\section{Background}

Due to its aggressive behavior and the high mortality rates, esophageal cancer (EC) is one of the deadliest cancers worldwide [1]. With $90 \%$, the main histological types of esophageal cancer are squamous cell- (ESCC) and adeno-carcinomas (EAC) [2]. The treatment and clinical practice of the EC remains a challenge $[3,4]$ because the importance of histology regarding the decision on the therapeutic approach has still not been settled. In this context, for example the establishment of gene expression profiles must be promote [5].

\footnotetext{
*Correspondence: klingelhoefer@med.uni-frankfurt.de

${ }^{1}$ Institute of Occupational, Social and Environmental Medicine, Goethe-

University, Theodor-Stern-Kai 7, 60590 Frankfurt, Germany

Full list of author information is available at the end of the article
}

In 2013, EC ranked 6th as cancer death cause worldwide and regarding the incidence of cancer cases 9th. It is estimated that 455,800 new cases and 400,200 death occurred in 2012 [6]. Men are at higher risk to develop EC than women. The incidence rates depend on the geographical region, sex and race. They vary internationally enormously by more than 21-fold [6] and reach the highest values in Southern and Eastern Africa and Eastern Asia, the lowest values in Western and Middle Africa and Central America [7]. A region called Esophageal Cancer Belt reaches from Iran to North-Central China is even since antiquity the highest risk region [1]. In the Western countries (e.g. USA, Australia, UK and France), the rates of EAC has been increasing tremendously, probably due to high prevalence of obesity, Barrett esophagus or chronic GERD (gastroesophageal reflux disease) $[8,9]$. In 
Asia on the other hand, the rate of ESCC increased considerably [8].

The major risk factors are remaining unclear. Even so, smoking, alcohol abuse, deficient or extremely salty diet [10], obesity and Barrett's esophagus or GERD can be declared as the main risk factors for the development of EC $[1,2]$. In some populations, the interaction of poverty or low socioeconomic status [11], nutritionally and social habits seem to increase the risk. Further risk factors of EC are the consumption of very hot liquids [12], the lack of fruits and vegetables [13], the drinking of mate tea through very hot metal tubes, the eating of residues form opium pipes, or chewing of betel nuts [14], to name just a few [1]. The reduced risk by the consumption of acetylsalicylic acid [15] may be explained by the rates of stem cell divisions. Here, the negative effects of acetylsalicylic acid intake must be mentioned as well [16].

The familial accumulation of EC has been shown in high incidence regions such as China [17]. If this is in fact due to a hereditary context is still not resolved until now.

Regarding the estimation of risk factors a differentiation between the ESCC and the EAC is absolutely necessary. Not every risk factor increases the likelihood of getting both types. Alcohol and hot liquids for instance are not linked to EAC, and the reflux diseases do not increase ESCC risk [2].

In contrast to the epidemiologic research on other cancer types $[18,19]$, there are still many unknown circumstances or uncertainties regarding the epidemiology of EC, e.g. the association between EC and Helicobacter pylori is still unclear [20].

The increasing incidence rates all around the world has not reached the zenith yet. The high mortality rate manifests the need to strengthen the research efforts to meliorate the prevention and the treatment of EC. The importance for better monitoring systems has been highlighted in other studies as well [21].

Therefore, the working group took the opportunity to evaluate the research output to depict a new map of the scientific approaches all over the world. The focus has been laid on the international networks, and the development of main topics. In this comprehensive survey the question of what are the most important influences of the research history has been addressed and answered as well as an outlook was given. This is not only important for the scientist but also for the planners, fund raisers and decision makers worldwide.

\section{Methods}

\section{Methodological platform and data source}

This study on the global research output on EC is part of the scientometric platform NewQIS (New Quality and Quantity Indices in Science) that has been generated by
Groneberg-Kloft in 2009 [22] to provide widespread information on a multitude of biomedical issues.

As data base, the Web of Science of Clarivate Analytics has been used. Its Core Collection supplies the interested and scientific users with publications and the respective bibliometric data. Additionally, it provides the associated citation numbers, so that the analysis of semi-qualitative aspects of the publication output can be carried out. The socio-economic data has been collected from the World Factbook [23].

\section{Search strategy}

The search term has been generated according to the principle of an extensive and representative literature study using the Entry Terms of the MesH Database (Medical Subject Headings) of the US National Library of Medicine (National Institutes of Health) [24]. Since these Entry Terms functions as a thesaurus for cataloguing the diseases, the completeness of the search query is guaranteed. The used search term was: "?esophag" AND ("cancer" OR "carcinom* OR "neoplasm*)". The asterisks replace an indefinite number of characters and has been applied to find different variations of the individual terms. The title search function was used. To include only the original articles in the investigation, the corresponding filter function of WoS was applied.

\section{Data analysis}

The resulting data pool has been integrated in a data base according to its bibliometric information and served as analysis basis. In the focus stood the development of the publication performance regarding $\mathrm{EC}$ and its global distribution. The influences over time and the impact of socio-economic features were evaluated too. Additionally, the citation analysis allowed qualitative insights of the scientific efforts and their backdrops. Here, the $\mathrm{h}$-index in a modified version (applied to the performance of countries) and the average citation rate were calculated and analyzed. Usually, the h-index is used as key indicator for the global reputation of an author in the scientific community. It is calculated by the number of publication that at least received the same number of citations each [25]. For further geographical evaluations, the number of articles was put into relation to the gross domestic product (GDP) and the population size of each country. The association between the number of articles and expenditures for research funding, respectively epidemiological conditions set another focus to this study by using linear regression [26, 27]. Furthermore, an analysis of the research areas and author's keywords has been carried out that permit statements on the main issues, chronologically and geographically. 


\section{Illustration of findings}

In part, the findings have been displayed by means of density equalizing map projections (DEMP). This technique represents a method to grab complex global circumstances at one glance by distorting the country sizes. An anamorphic map is the result of the compensation of the osmotic density gradient of the evaluated parameter (e.g. publication number, citation number) [28].

\section{Results}

\section{Chronological analyses}

All in all, the bibliometric data of 17,387 original articles (n) was retrieved. Out of this pool, 16,230 articles were written in English (93.3\%). The second most used language was French with $2.47 \%(\mathrm{n}=430)$, followed by German $(\mathrm{n}=395)$ and Russian $(\mathrm{n}=172)$.

The number of articles on EC were initially remaining below $\mathrm{n}=10$ until the end of the Second World War 1945. Afterwards, a moderate but steady increase could be observed until 1980. From then onwards, the numbers increased much faster until they reached their maximum in 2016 with $n=1331$ articles. The numbers of citations (c) showed a similar development with peaks in 1994 $(\mathrm{c}=10.631)$ and $2001(\mathrm{c}=15.258)-$ until its maximum in $2005(\mathrm{c}=16.032)$. Afterwards, the annual amount decreased very rapidly with only small peaks in 2008 $(\mathrm{c}=14.951)$ and $2012(\mathrm{c}=13.664)$. Comparing the citation rates (cr) of the publication years, the years 1946 ( $\mathrm{cr}=56.6), 1998(\mathrm{cr}=47.5)$ and $1961(\mathrm{cr}=41.4)$ were outstanding.

\section{Geographical analyses}

The information of the country of origin was given in the field tags of 16,686 articles $(95.9 \%)$. This pool was the source of the geographical analyses and represents the timespan between 1973 and 2017. Previous to this time frame, the geographical data is non-existent, respectively very limited.

The evaluation of absolute numbers (Fig. 1a) shows that China is the most publishing country with $n=4448$ articles on EC, followed by Japan $(\mathrm{n}=3828)$ and the USA $(n=3125)$. Following behind with some distance, Germany and the UK reached $n=999$ and $n=952$, respectively.

The chronological development of the relative proportion of the most publishing countries is shown in Fig. 1b. Chinas share increased from 1.39 to $45.30 \%$. In contrast, the USA proportion decreased from 30.09 to $13.53 \%$. The order of the five most publishing countries in the first evaluation interval (1973-1977) is as follows: USA $(n=65)$, France $(n=57)$, UK $(n=21)$, Germany $(n=18)$, and Japan $(\mathrm{n}=14)$. From 1988 to 2007, Japan published the most part of the OC-articles. The last time evaluation period (2013-2017) is ranked as follows: China $(\mathrm{n}=2722)$, Japan $(\mathrm{n}=928)$, USA $(\mathrm{n}=813)$, UK $(\mathrm{n}=268)$, and Germany $(\mathrm{n}=193)$.

The USA received the most citations $(\mathrm{c}=103,833)$, followed by Japan $(c=81,099)$, China $(c=61,726)$, and also at some distance by the UK $(c=27,607)$ and Germany (c=26,095) (Fig. 2a).

Assessing the modified h-indices (hI) of the publishing countries (Fig. 2b) the order of the first five countries is as follows: USA ( $\mathrm{hI}=134)$, Japan $(\mathrm{hI}=106)$, China $(\mathrm{hI}=89)$, $\mathrm{UK}(\mathrm{hI}=78)$ and Germany (hI=73). Regarding the average citation rate $(\mathrm{cr})$ of countries with more or equal 30 articles (threshold), Belgium is the leading country with $\mathrm{cr}=53.75$, followed by Singapore $(\mathrm{cr}=38.76)$, USA $(\mathrm{cr}=33.22)$, Norway $(\mathrm{cr}=32.10)$ and Canada $(\mathrm{cr}=31.40)$ to name the best five (Fig. 2c).

To give consideration to the differences regarding the number of inhabitants and the economic strength (threshold $\geq 30$ articles), the ratios of the number of articles/population in mill. $\left(\mathrm{R}_{\mathrm{POP}}\right)$ and the number of articles/GDP in 1000 bn USD $\left(R_{\mathrm{GDP}}\right)$ were analyzed (Fig. 3). It is notable that High-income (HI) countries were ranked higher in principle regarding both parameters, especially Japan $\left(\mathrm{R}_{\mathrm{POP}}=30.21, \mathrm{R}_{\mathrm{GDP}}=776.15\right)$, Netherlands $\left(R_{\mathrm{POP}}=29.97, \mathrm{R}_{\mathrm{GDP}}=588.98\right)$, and Sweden $\left(R_{\mathrm{POP}}=29.55, \mathrm{R}_{\mathrm{GDP}}=586.23\right)$. In this analysis, the countries with a lower income level are set back. Especially China-ranking first regarding the absolute evaluation numbers-has been thrown back.

\section{Influence of research funding and incidence rates}

Looking at the association between the publication output of the countries and the overall expenditures on Research and Development in mill. US-Dollars (R\&D), [26] respectively the countries' epidemiological burdens [27] (OECD countries), differences regarding the adequacy of individual research endeavors reveals. For the linear regression of the numbers of articles and the $R \& D$ expenditures a coefficient of determination $\left(\mathrm{r}^{2}\right)=0.79$ can be calculated. The correlation is strongly significant (Spearman $\mathrm{p}<0.0001$ ), while the correlation between the number of articles and the incidence crude rate (ICR) with $r^{2}=0.44$ and $p=0.0122$ shows only a weak significant association. Therefore, the influence of the funding seems to be stronger that the disease burden or the associated expenses.

Despite the significant correlation of the funding expenditures and the publication output, the individual countries showed a very different publication behavior (Fig. 4). To analyze the deviations from the regression line, the residuals were calculated and compared (Fig. 5). Striking is the negative position of the USA (Fig. 4a). 


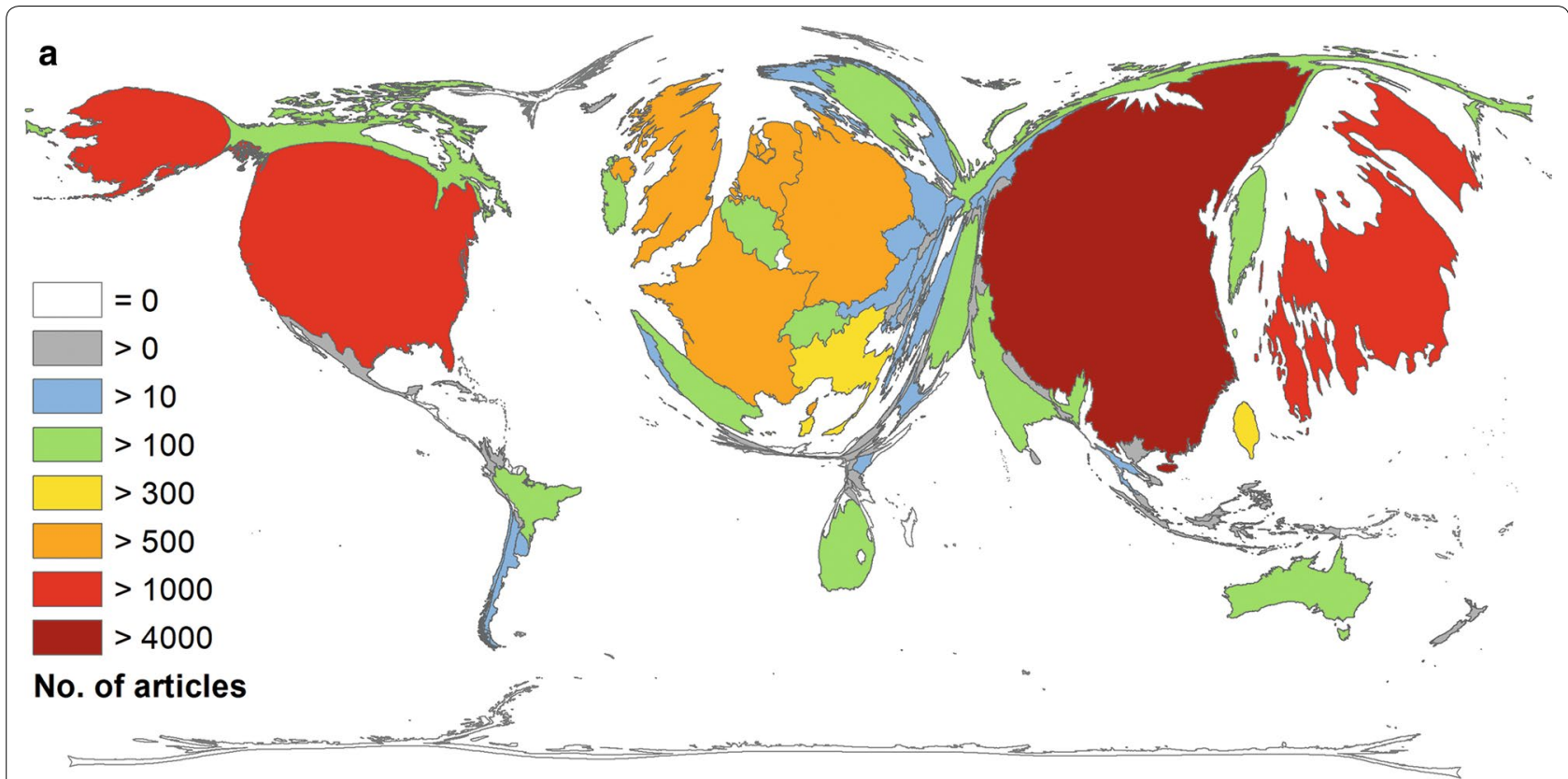

b

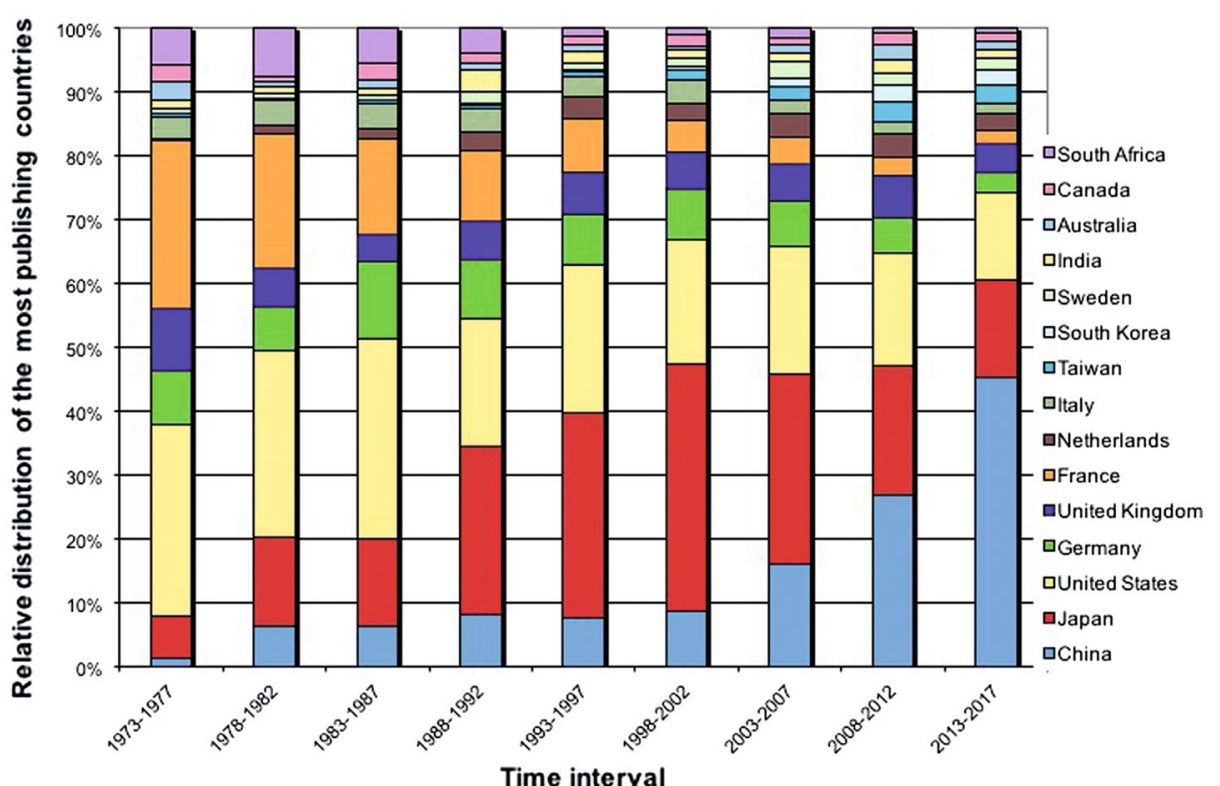

Fig. 1 Density equalizing map projection of the absolute numbers of the publishing countries. a Number of articles. $\mathbf{b}$ The development of the relative distribution of the most publishing countries in 5-year intervals from 1973 until 2017

The published very little compared to their overall research expenditures $(R \& D=456.90, n=3125)$. In contrast, Japan published relatively much $(R \& D=154.71$, $\mathrm{n}=3828)$. Additionally, France $(\mathrm{R} \& \mathrm{D}=55.79, \mathrm{n}=858)$, UK $(R \& D=41.78, n=952)$, Italy $(R \& D=27.05, n=391)$ and the Netherlands $(R \& D=15.44, n=510)$ participated relatively much. China published the most, but with a high funding background ( $R \& D=376.90, n=4448$ ). Germany $(\mathrm{R} \& \mathrm{D}=101.58, \mathrm{n}=999)$ and South Korea showed
( $R \& D=73.59, \quad n=293)$ a slightly negative endeavor on EC research comparing to their overall research expenditure.

Analyzing the publication output regarding the epidemiological EC burden of the OECD countries measured by the ICR, the picture is different (Fig. 4b). Here, UK $(\mathrm{ICR}=14)$ and Netherlands $(\mathrm{ICR}=12.5)$ with a very high rate published only little, while the USA a higher contribution made referring to the values of 2012 [27]. 


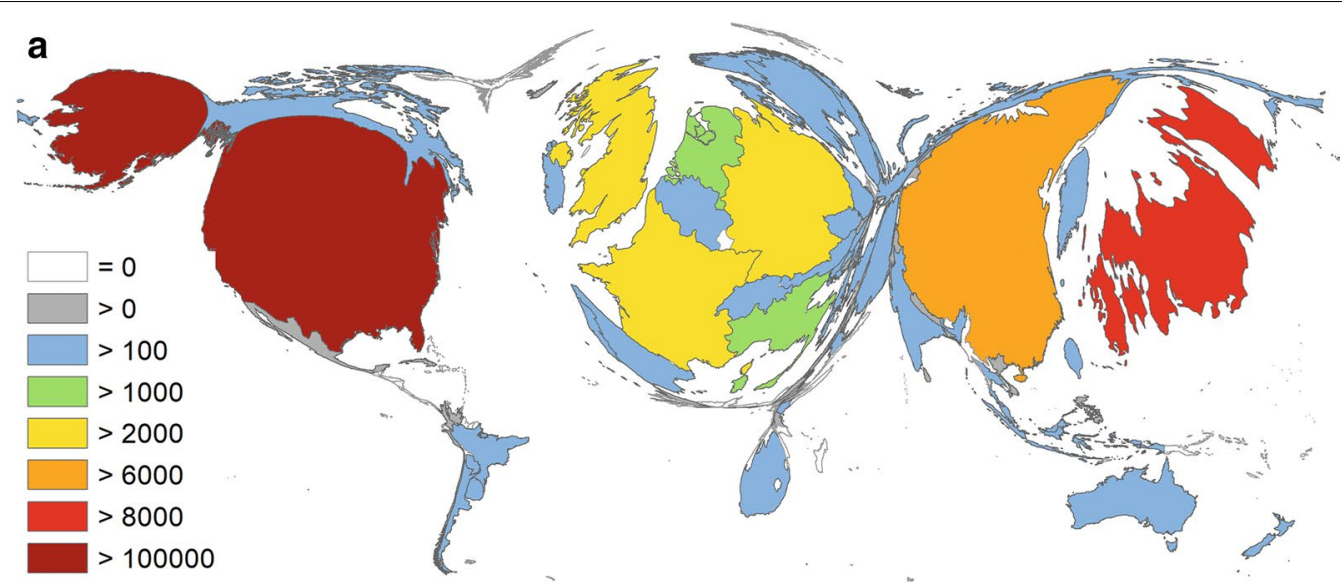

No. of citations

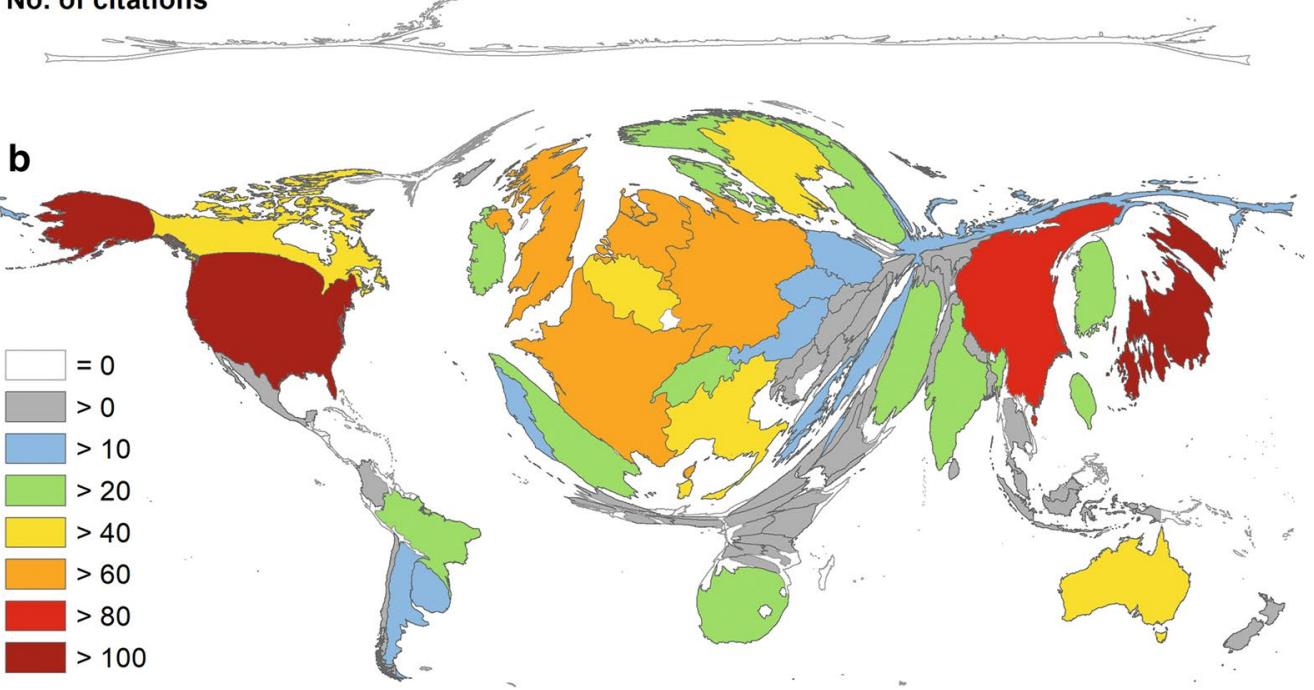

Mod. h-Index

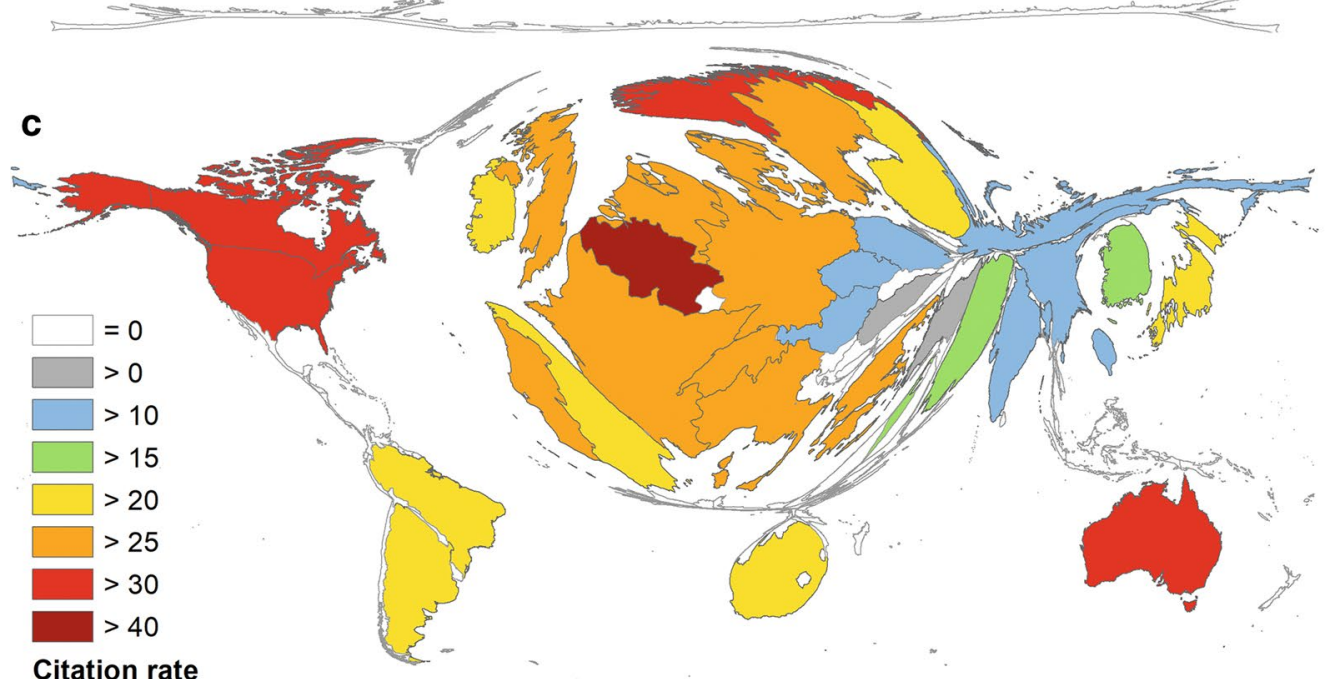

Citation rate

Fig. 2 Density equalizing map projection of citation parameters. a Number of citations. b Modified h-index. c Citation rate (threshold $\geq 30$ articles) 


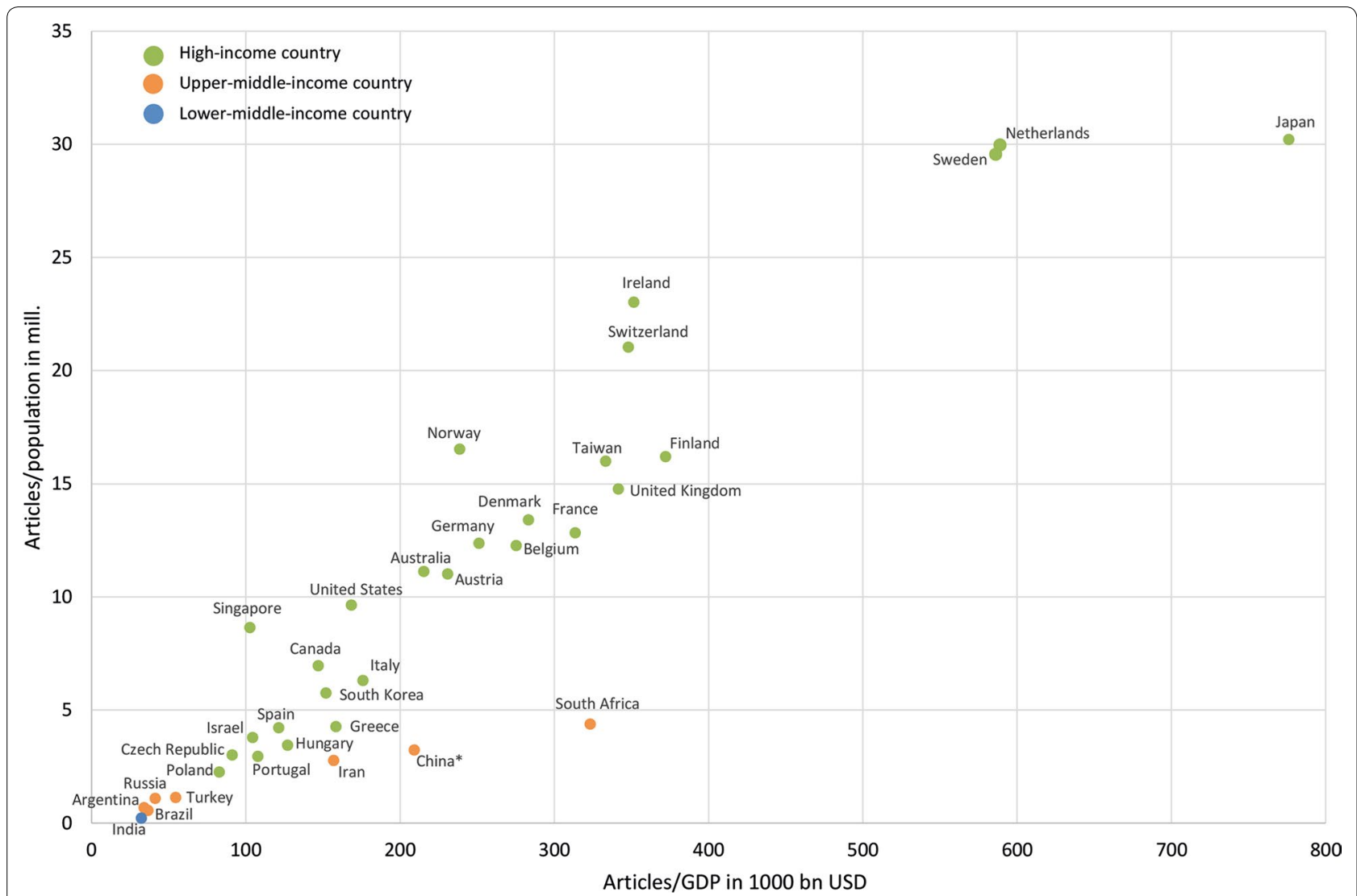

Fig. 3 Socio-economic parameters of the countries publishing on esophageal cancer, threshold $\geq 30$ articles, GDP gross domestic product, USD US-Dollar, countries income groups according to the World Bank classification

Also, Ireland $(\mathrm{ICR}=9.3)$ and Belgium $(\mathrm{ICR}=9)$ following regarding their ICR were participating very little EC articles. With even higher ICRs, China (ICR $=16.4)$ and Japan $(\mathrm{ICR}=15.6)$ worked more on $\mathrm{EC}$, although on slightly negative positions.

\section{Collaboration analyses}

The international collaboration network is wide ranging (Fig. 6), but the highest number of cooperation articles were worked out under participation of China and USA with 513 common articles. In addition, the cooperation between Japan and USA with 129 collaboration articles is worth mentioning. China produced 783 of its overall 4448 articles on OC together with another country (17.60\%). In contrast, Japan wrote only $7 \%(n=268$ of 3828 ) in international cooperation. With $33.73 \%$ the USA published more than one-third of its overall articles together with other countries $(n=1054$ of 3125), whereof nearly half has been worked out with China (48.87\%).

\section{Research areas}

The most assigned subject areas (according to the WoS classification) are Oncology with $\mathrm{n}=6972$ articles, Surgery $(\mathrm{n}=4282)$, Gastroenterology \& Hepatology $(\mathrm{n}=2985)$, Radiology \& Nuclear Medicine \& Medical Imaging $(\mathrm{n}=1126)$ and General \& Internal Medicine $(\mathrm{n}=1126)$.

Looking at the alteration in the relative distribution of the ten most assigned subject areas in 5-year intervals from 1968 until 2017 (Fig. 7a), it can be stated that Oncology und Gastroenterology \& Hepatology relatively increased from 10.16 to $42.13 \%$, while the proportion of Surgery decreased from 28.34 to $14.95 \%$. Only since 1993, Biochemistry \& Molecular Biology appeared among the ten best with only $0.13 \%$, but increased on a moderate level until 2017 (3.21\%). The comparison of the most publishing countries (Fig. 7b) revealed differences regarding the proportion of Surgery among the ten most assigned subject areas. In China, this area is clearly underrepresented (3.27\%), whereas here Biochemistry \& Molecular Biology is more noticeable than in the other countries. 

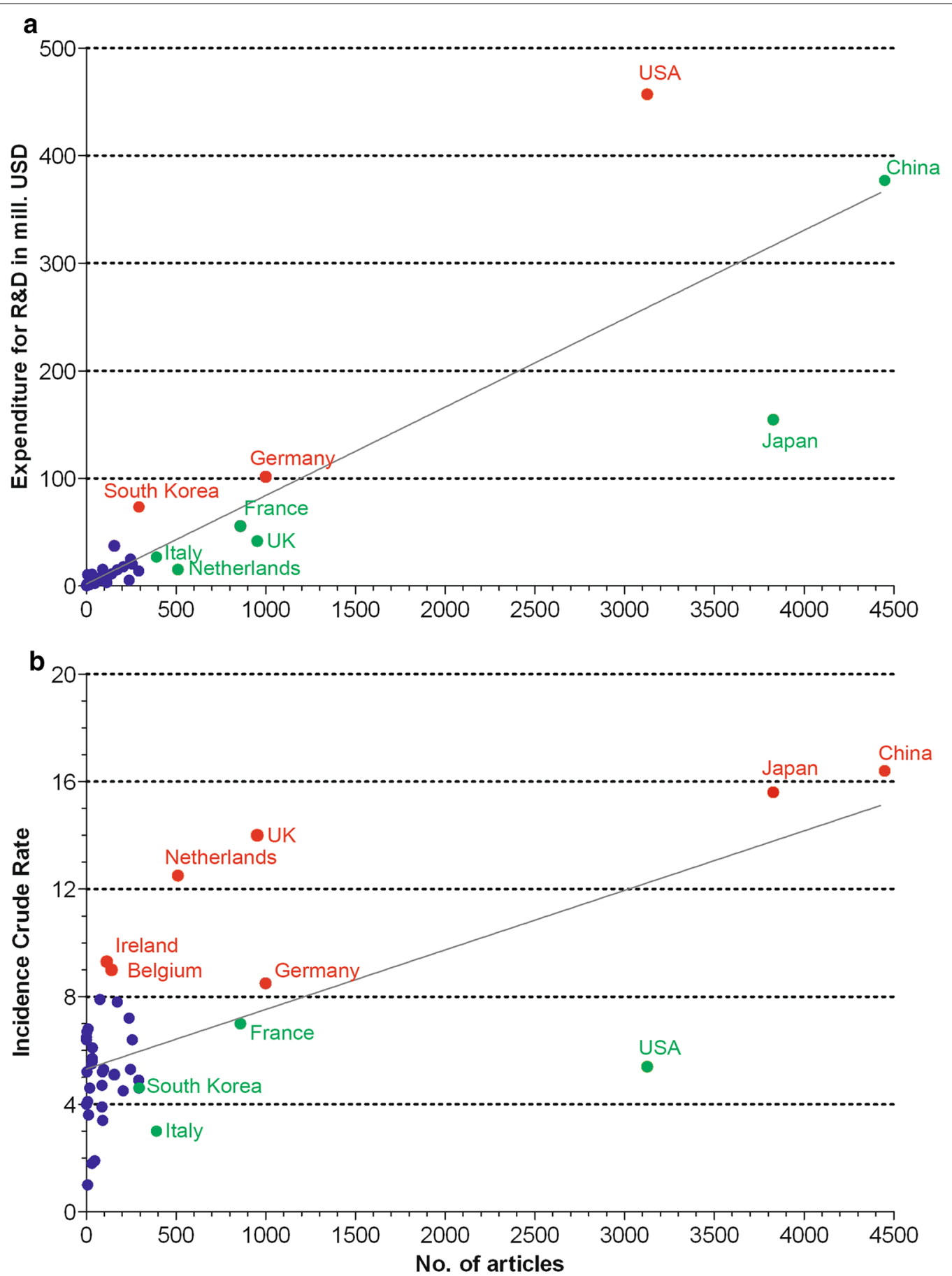

Fig. 4 OECD countries. a Association between the number of articles and the expenditures for Research and Development (R\&D). b Association between the number of articles and the incidence crude rate, red spots=negative residuals, green spots= positive residuals, dark blue spots $=$ countries with numbers of articles $<100$

\section{Discussion}

\section{Methodical strength and limitations}

The enormous amount of scientific publications and the increasing range of journals makes it absolutely necessary to separate the wheat from the chaff. Not only for the individual scientists, but also for planners and funders it is getting more and more difficult to assess the available literature as well as the scientific environment. A 


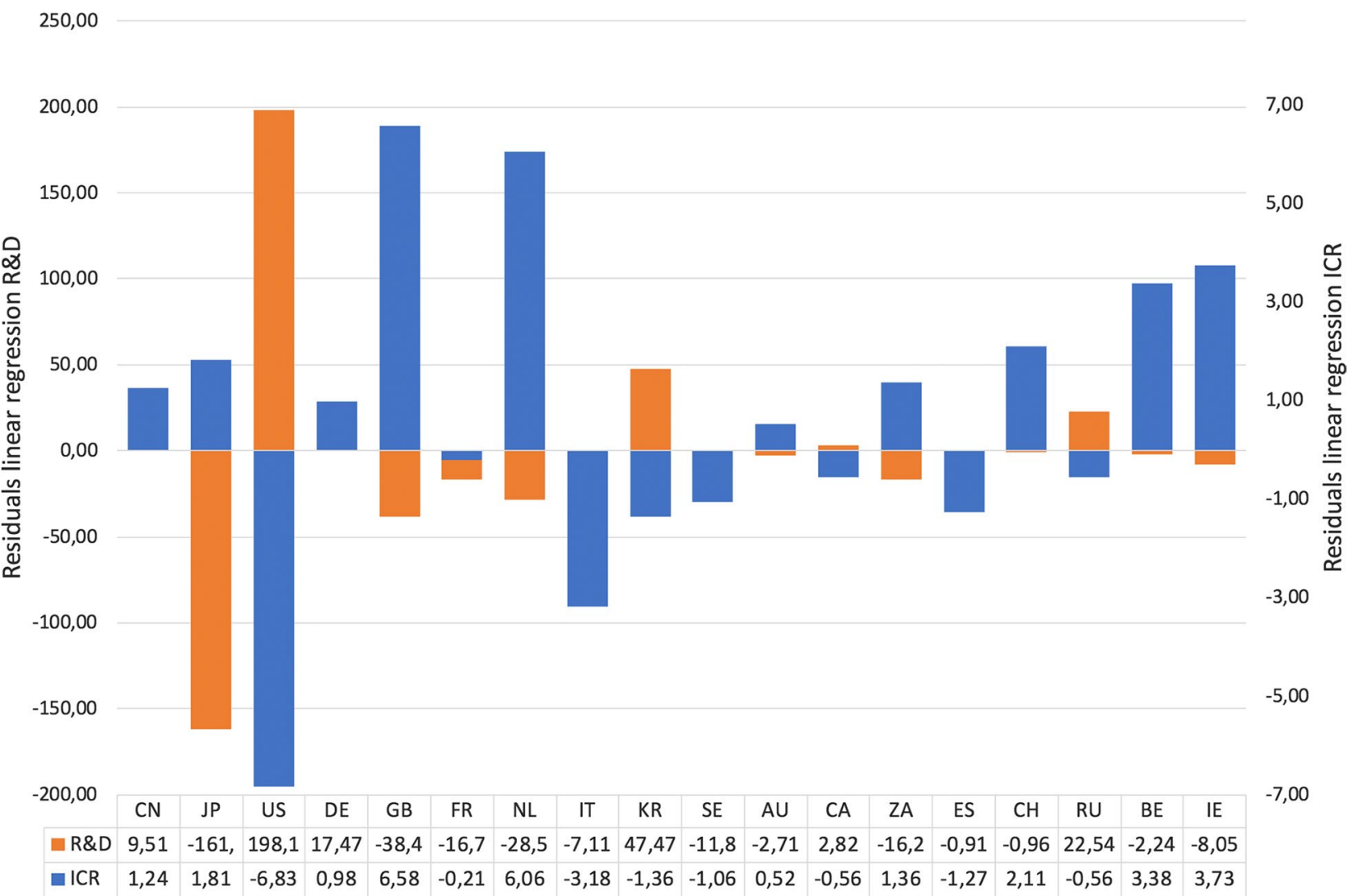

Fig. 5 Residuals of the linear regression between the number of articles and the expenditures for research and development in mill. US-Dollar (R\&D) and the number of articles and the incidence crude rate (ICR). Threshold $=100$ articles. Sorting according to number of articles. Officially countries' Alpha-2 codes ( $C N=$ China, JP = Japan, US = USA, DE= Germany, GB= United Kingdom, FR=France, NL=Netherlands, IT=Italy, $\mathrm{KR}=$ South Korea, $\mathrm{SE}=$ Sweden, $\mathrm{AU}=$ Australia, $\mathrm{CA}=$ Canada, $\mathrm{ZA}=$ South Africa, $\mathrm{ES}=$ Spain, $\mathrm{CH}=$ Switzerland, $\mathrm{RU}=\mathrm{Russia}, \mathrm{BE}=\mathrm{Belgium}$, $\mathrm{IE}=$ |reland)

long-sighted and globally adapted research is in demand, especially regarding medical issues. So, the NewQIS platform select important medical topics to carry out comprehensive bibliometric reviews. All bibliometric studies depend on the representative status of the database. The WoS is certainly one of the most prolific literature and citation data bases worldwide, but nevertheless, some disadvantages have to be discussed. The English-bias has already been shown in a variety of articles [29, 30]. Even so, possible faulty citing $[31,32]$ leads to methodological limitation, since the citation numbers are underlying all citation parameters. Therefore, the interplay of the applied citation parameters seems to provide the highest benefit. Likewise, the generation of the applied search term is controversial. The more extensive the data base, the more faultily integrated entries can disturb its quality, and the resulting validity can be brought into question. On the other hand, a data base should be as complete as possible because otherwise it harbours the risk of neglecting important data. Hence, it is a tightrope walk to elaborate a scientifically adequate term and the appropriate strategy.

\section{Discussion of results}

The development of the number of publications follows a known pattern. It has been proofed earlier that the increase of articles number show an exponential progression (Table 1) [33]. Nevertheless, the visible maxima of average citation numbers per year illustrate an association with the most prolific articles (Table 2) [34-37].

Additionally, the incidence of EAC in the Western countries has increased tremendously in the last decades [8], so that the significant increase of publications on EC in the last years seems reasonable [38]. The high incidence and prevalence rates of the so called Esophageal Cancer Belt leading from Iran, Central Asia to North China cause the high participation of China ranking first. Nearly half of the new OC cases worldwide occurred in China in 2012 [6]. Here, OC ranked 4th regarding the incidence rate after lung, stomach and liver cancer [38] 


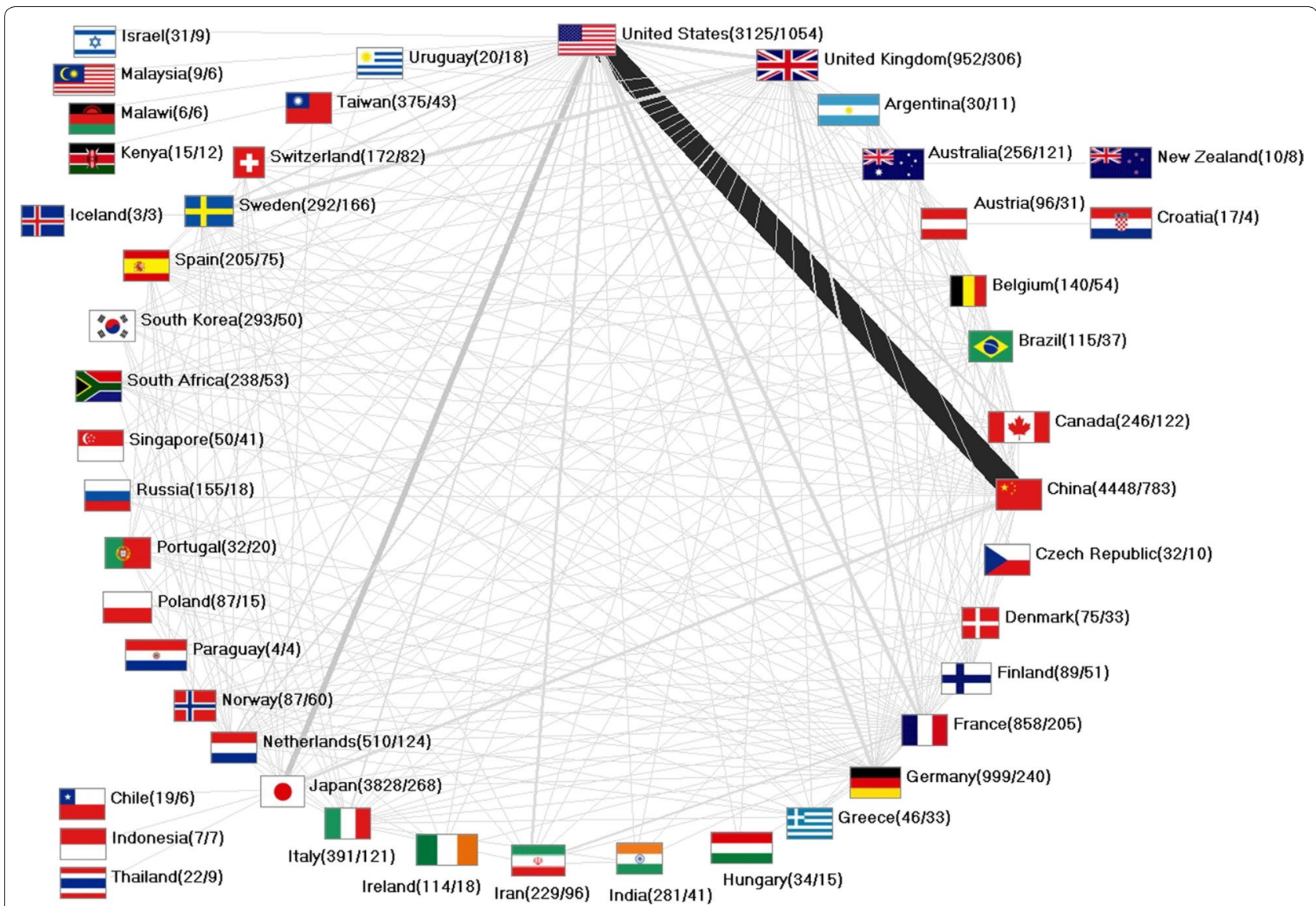

Fig. 6 International network of the countries publishing on esophageal cancer, numbers in brackets (number of articles/number of collaboration articles)

and also regarding the mortality rate [39]. After all, Iran still ranks 15th with 229 articles. Other belt-countries can be neglected.

The publication output regarding the ratios of the socio-economic factors mat the findings of Man et al. which emphasize the dominancy e.g. of Scandinavian countries, certainly because of the National Cancer Registries that are delivering the clinical data [40-42]. The main difference of both study results is the position of Japan. Despite the low incidence and mortality rate in Japan [43] the research effort on EC is remarkable. Man et al. [44] positioned Japan in the lower part of the ranking regarding the $\mathrm{R}_{\mathrm{POP}}$ value. In our review, Japan ranks second regarding the absolute numbers of the publication output, and ranks first regarding both socio-economic features $\left(R_{\mathrm{POP}}, \mathrm{R}_{\mathrm{GDP}}\right)$ (Table 2). Regarding the influence of the Total Research Spending, Man et al. [44] found Japan equally high ranked as in our study. This was confirmed by our findings that show that Japan position regarding their expenditures on R\&D was extremely positive. It showed a slightly discarded position in comparison to their high ICR. Japan already established several institutions, working groups, and studies with the focus on EC. The Japan Esophageal Society for example, publishing the Esophagus Journal, generated the Comprehensive registry of EC. Additionally, the Japan Esophageal Cancer Group has been created as one of the first two Groups of the Japan Clinical Oncology Group (JCOG) in 1978. However, with only $7 \%$ international collaborations, for Japan can be calculated the lowest cooperation percentage of all HI-countries publishing on EC.

Despite their ranking among the best five, the publication performance on EC of the USA and the UK is relatively low compared with other studies [45-47]. An analysis of research funding on cancer burden measured by estimated medical costs and years life lost (YLL) stated the underfunding of EC research in both countries [48]. The correlation analysis of this study regarding the connection of the article numbers and the ICR showed a positive participation of US-American scientists based on the Globocan numbers of 2012 [27]. However, there has recently been an extreme accumulation of 

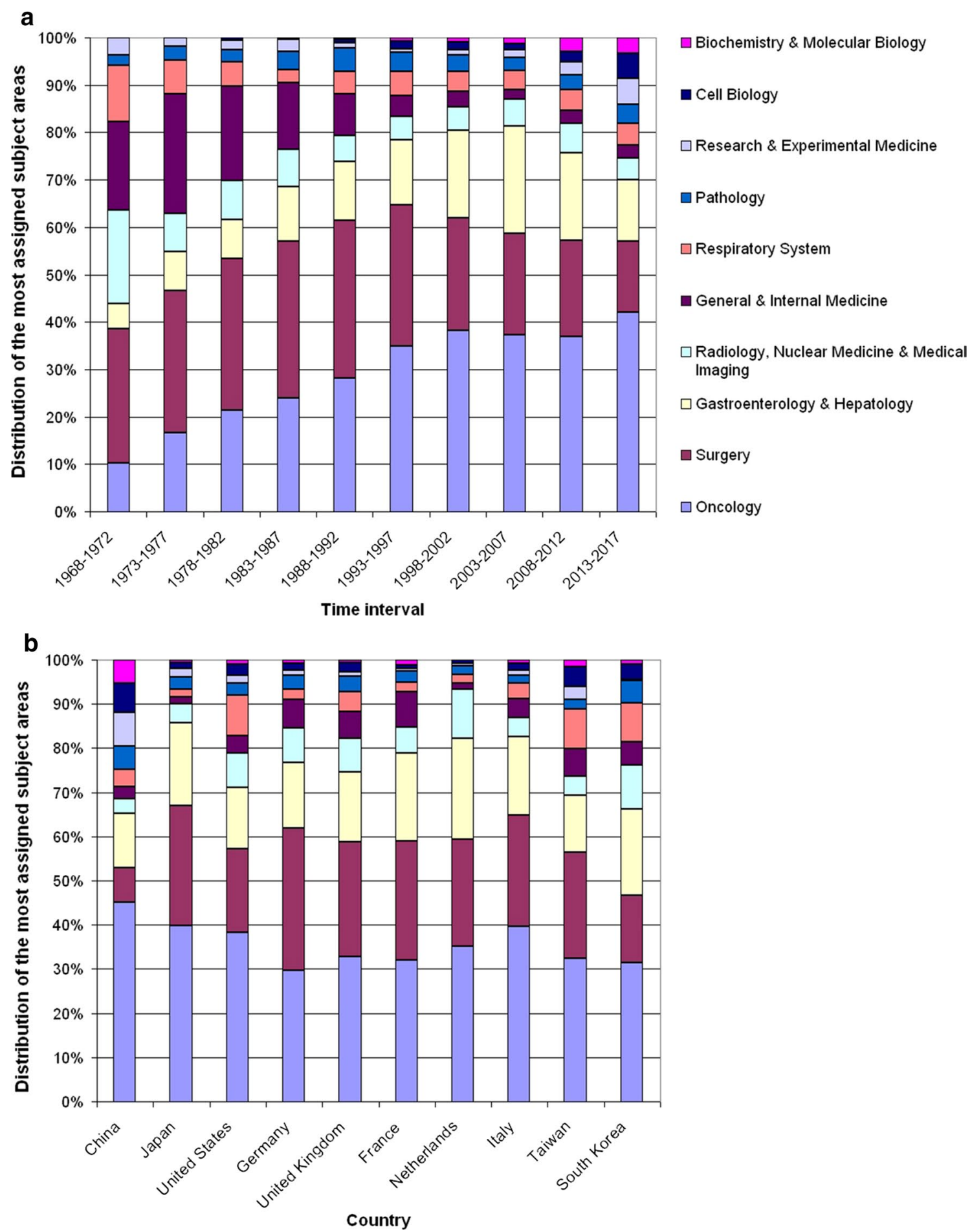

Fig. 7 The most assigned subject areas. a Relative distribution in 5-year intervals. b Relative distribution of the most publishing countries

EAC cases, so that these findings have to be adapted in future. Despite the currently alarming figures of EAC in the US, the NCI decreased the funding of EC research by $15 \%$ in 2012 . Only about $0.5 \%$ of the overall budget was invested. And the American Cancer Society funded only eight OC projects out of 1165 cancer projects [48]. This was confirmed by our findings. They positioned the 
Table 1 Socio-economic parameters of 10 top ranked countries regarding the $R_{G D P}=$ articles/GDP in 1000 bn UDS (GDP $=$ gross domestic product), $\mathbf{R}_{\mathrm{POP}}=$ articles/population, total in mill. inhabitants (threshold $=\mathbf{3 0}$ articles)

\begin{tabular}{|c|c|c|c|c|c|}
\hline Country & No. of articles & GDP in 1000 bn UDS & Population in mill. & $\mathrm{R}_{\mathrm{GDP}}$ & $\mathrm{R}_{\mathrm{POP}}$ \\
\hline Japan & 3828 & 4.93 & 126.70 & 776.16 & 30.21 \\
\hline Netherlands & 510 & 0.86 & 17.02 & 588.98 & 29.97 \\
\hline Sweden & 292 & 0.49 & 9.88 & 586.23 & 29.55 \\
\hline Finland & 89 & 0.23 & 5.50 & 372.07 & 16.19 \\
\hline Ireland & 114 & 0.32 & 4.95 & 351.53 & 23.02 \\
\hline Switzerland & 172 & 0.49 & 8.18 & 347.97 & 21.03 \\
\hline United Kingdom & 952 & 2.78 & 64.43 & 341.46 & 14.78 \\
\hline Taiwan & 375 & 1.12 & 23.46 & 333.33 & 15.98 \\
\hline South Africa & 238 & 0.73 & 54.30 & 323.24 & 4.38 \\
\hline France & 858 & 2.73 & 66.84 & 313.48 & 12.84 \\
\hline Denmark & 75 & 0.26 & 5.59 & 283.23 & 13.41 \\
\hline Belgium & 140 & 0.51 & 11.41 & 275.27 & 12.27 \\
\hline Germany & 999 & 3.98 & 80.72 & 251.07 & 12.38 \\
\hline Norway & 87 & 0.36 & 5.27 & 238.55 & 16.52 \\
\hline Austria & 96 & 0.41 & 8.71 & 230.82 & 11.02 \\
\hline Australia & 256 & 1.19 & 22.99 & 215.31 & 11.13 \\
\hline China & 4448 & 21.27 & 1373.54 & 209.12 & 3.24 \\
\hline Italy & 391 & 2.22 & 62.01 & 176.05 & 6.31 \\
\hline USA & 3125 & 18.56 & 324.00 & 168.37 & 9.65 \\
\hline Greece & 46 & 0.29 & 10.77 & 158.35 & 4.27 \\
\hline Iran & 229 & 1.46 & 82.80 & 156.96 & 2.77 \\
\hline South Korea & 293 & 1.93 & 50.92 & 151.89 & 5.75 \\
\hline Canada & 246 & 1.67 & 35.36 & 146.95 & 6.96 \\
\hline Hungary & 34 & 0.27 & 9.87 & 127.06 & 3.44 \\
\hline Spain & 205 & 1.69 & 48.56 & 121.30 & 4.22 \\
\hline Portugal & 32 & 0.30 & 10.83 & 107.71 & 2.95 \\
\hline Israel & 31 & 0.30 & 8.17 & 104.38 & 3.79 \\
\hline Singapore & 50 & 0.49 & 5.78 & 102.69 & 8.65 \\
\hline Czech Republic & 32 & 0.35 & 10.64 & 91.19 & 3.01 \\
\hline Poland & 87 & 1.05 & 38.52 & 82.70 & 2.26 \\
\hline Turkey & 91 & 1.67 & 80.27 & 54.49 & 1.13 \\
\hline Russia & 155 & 3.74 & 142.36 & 41.39 & 1.09 \\
\hline Brazil & 115 & 3.13 & 205.82 & 36.68 & 0.56 \\
\hline Argentina & 30 & 0.88 & 43.89 & 34.11 & 0.68 \\
\hline India & 281 & 8.72 & 1266.88 & 32.22 & 0.22 \\
\hline
\end{tabular}

number of articles on EC in comparison to their overall $R \& D$ expenditures last among the OECD countries.

After the findings of this study, the UK positioned itself with a high ICR of 14 and $n=952$ article behind. However, the UK works on EC seems to be in line when looking at their overall R\&D expenditures. Also, Carter et al. [49] found that the under-funded research on EC, shifted somewhat towards an improved funding from 2000 to 2010. This may be due to the largely nationalized medical system, while in the US only a scarce state health system is established. This led to more prevention measures, more check-ups and more available medical data in UK [49].

Comparing the publication output of other European Countries, a back lying can be stated when looking at the high ICR in 2012. Here, the Netherland, Ireland, Belgium has to be highlighted. Especially the most affected countries in Europa are publishing comparatively little on EC. Looking at the highly affected countries worldwide with ICR over 15, only China and Japan show a justified research endeavor on EC. Other highly affected 
Table 2 The most cited articles

\begin{tabular}{|c|c|c|c|c|}
\hline Country & Authors & Years & Citations & Title \\
\hline USA & Devesa et al. & 1998 & 1484 & $\begin{array}{l}\text { Changing patterns in the incidence of esophageal and gastric carci- } \\
\text { noma in the United States }\end{array}$ \\
\hline $\begin{array}{l}\text { South Korea, Belgium, Switzerland, } \\
\text { China, Japan, Germany, Italy, Russia, } \\
\text { Australia }\end{array}$ & Bang et al. & 2010 & 1312 & $\begin{array}{l}\text { Trastuzumab in combination with chemotherapy versus chemo- } \\
\text { therapy alone for treatment of HER2-positive advanced gastric or } \\
\text { gastro-oesophageal junction cancer (ToGA): a phase 3, open-label, } \\
\text { randomised controlled trial }\end{array}$ \\
\hline USA & Herskovic et al. & 1992 & 1301 & $\begin{array}{l}\text { Combined chemotherapy and radiotherapy compared with radio- } \\
\text { therapie alone in patients with cancer of the esophagus }\end{array}$ \\
\hline Netherlands & van Hagen et al. & 2012 & 1117 & Preoperative chemoradiotherapy for esophageal or junctional cancer \\
\hline UK & Cunningham et al. & 2008 & 1025 & Capecitabine and oxaliplatin for advanced esophagogastric cancer \\
\hline France, Belgium & Bosset et al. & 1997 & 898 & $\begin{array}{l}\text { Chemoradiotherapy followed by surgery compared with surgery } \\
\text { alone in squamous-cell cancer of the esophagus }\end{array}$ \\
\hline USA & Cooper et al. & 1999 & 872 & $\begin{array}{l}\text { Chemoradiotherapy of locally advanced esophageal cancer-long- } \\
\text { term follow-up of a prospective randomized trial (RTOG 85-01) }\end{array}$ \\
\hline France & Mandard et al. & 1994 & 842 & $\begin{array}{l}\text { Pathological assessment of tumor-regression after preoperative } \\
\text { chemoradiotherapy of esophageal-carcinoma }\end{array}$ \\
\hline USA, Canada & Kelsen et al. & 1998 & 837 & $\begin{array}{l}\text { Chemotherapy followed by surgery compared with surgery alone for } \\
\text { localized esophageal cancer }\end{array}$ \\
\hline USA & Urba et al. & 2001 & 813 & $\begin{array}{l}\text { Randomized trial of preoperative chemoradiation versus surgery } \\
\text { alone in patients with locoregional esophageal carcinoma }\end{array}$ \\
\hline
\end{tabular}

countries-especially developing countries-did not play a role in the research landscape of EC.

Therefore, the targeted promotion of established science systems and their scientists under the current conditions is highly required and the most affected countries without financial recourses for adequate research efforts have to be supported and included in the global scientific network. Here, a rethink must take place, which leads to a redistribution of resources.

\section{Conclusions}

The unclear epidemiological correlations and the involved bad basis for evaluation complicates the possibility to develop successful prevention measures for EC. Additionally, the extremely geographically and histologically varying incidence rates make the generation of solution approaches very difficult. Therefore, the need for further research seems essential. The increase of new cases in Western countries and the under-funding of EC research shows a significant demand for decision makers, funders and scientists. The low collaboration preparedness of the most acting countries and the weak participation of highly affected countries elucidate the support of countries with an elaborated scientific basis. The challenge in this respect is to optimize research and research funding in accordance with the cancer burden. The establishing of functional health systems can improve the access to reliable data so that adequate strategies can be developed. There is a large demand for multidisciplinary approaches to fulfil the complex scientific issues related to EC.

\section{Acknowledgements \\ Not applicable.}

\section{Authors' contributions}

DK, DAG contributed to conception and design. DK, YZ, DB, MB, NS, DAG contributed to the analyses, the interpretation of data and the draft of the article. DK wrote the article. DK, YZ, MB, DB, NS, DAG revised the article. All authors read and approved the final manuscript.

\section{Funding}

There have been no financial supports for this study.

\section{Availability of data and materials}

The analyses bibliometric data is owned by the Web of Science database of Clarivate Analytics. Any researcher with access to the Web of Science database can obtain the data using the methods described in the paper.

\section{Ethics approval and consent to participate}

Not applicable.

\section{Consent for publication \\ Not applicable.}

\section{Competing interests}

The authors declare that they have no competing interests.

\section{Author details}

1 Institute of Occupational, Social and Environmental Medicine, Goethe-University, Theodor-Stern-Kai 7, 60590 Frankfurt, Germany. ${ }^{2}$ Integrative Medicine Centre, 302 Military Hospital, Beijing, China.

Received: 15 April 2019 Accepted: 30 April 2019

Published online: 10 May 2019 


\section{References}

1. Karamanou M, Markatos K, Papaioannou TG, Zografos G, Androutsos G. Hallmarks in history of esophageal carcinoma. J BUON. 2017;22(4):1088-91.

2. Enzinger PC, Mayer RJ. Esophageal cancer. N Engl J Med. 2003;349(23):2241-52

3. Klevebro F, Ekman S, Nilsson M. Current trends in multimodality treatment of esophageal and gastroesophageal junction cancer-review article. Surg Oncol. 2017;26(3):290-5.

4. Hou XB, Wen JX, Ren ZP, Zhang GL. Non-coding RNAs: new biomarkers and therapeutic targets for esophageal cancer. Oncotarget. 2017:8(26):43571-8

5. Visser E, Franken IA, Brosens LAA, Ruurda JP, van Hillegersberg R. Prognostic gene expression profiling in esophageal cancer: a systematic review. Oncotarget. 2017;8(3):5566-77.

6. Torre LA, Bray F, Siegel RL, Ferlay J, Lortet-Tieulent J, Jemal A. Global cancer statistics, 2012. CA Cancer J Clin. 2015;65(2):87-108.

7. Jemal A, Bray F, Center MM, Ferlay J, Ward E, Forman D. Global cancer statistics. CA Cancer J Clin. 2011;61(2):69-90.

8. Pohl H, Sirovich B, Welch HG. Esophageal adenocarcinoma incidence: are we reaching the peak? Cancer Epidemiol Biomark Prev. 2010;19(6):1468-70.

9. Pennathur A, Gibson MK, Jobe BA, Luketich JD. Oesophageal carcinoma. Lancet. 2013;381(9864):400-12.

10. Wiseman M. The second World Cancer Research Fund/American Institute for Cancer Research expert report. Food, nutrition, physical activity, and the prevention of cancer: a global perspective. Proc Nutr Soc. 2008;67(3):253-6.

11. Gammon MD, Schoenberg JB, Ahsan H, Risch HA, Vaughan $T L$, Chow WH, et al. Tobacco, alcohol, and socioeconomic status and adenocarcinomas of the esophagus and gastric cardia. J Natl Cancer Inst. 1997:89(17):1277-84

12. Islami F, Pourshams A, Nasrollahzadeh D, Kamangar F, Fahimi S, Shakeri $\mathrm{R}$, et al. Tea drinking habits and oesophageal cancer in a high risk area in northern Iran: population based case-control study. BMJ. 2009;338:b929.

13. Liu J, Wang J, Leng Y, Lv C. Intake of fruit and vegetables and risk of esophageal squamous cell carcinoma: a meta-analysis of observational studies. Int J Cancer. 2013:133(2):473-85.

14. Akhtar S, Sheikh AA, Qureshi HU. Chewing areca nut, betel quid, oral snuff, cigarette smoking and the risk of oesophageal squamous-cell carcinoma in South Asians: a multicentre case-control study. Eur J Cancer. 2012;48(5):655-61.

15. Lopez-Lazaro M. Understanding why aspirin prevents cancer and why consuming very hot beverages and foods increases esophageal cancer risk. Controlling the division rates of stem cells is an important strategy to prevent cancer. Oncoscience. 2015:2(10):849-56.

16. Mund ME, Gyo C, Bruggmann D, Quarcoo D, Groneberg DA. Acetylsalicylic acid as a potential pediatric health hazard: legislative aspects concerning accidental intoxications in the European Union. J Occup Med Toxicol. 2016;11:5

17. Chang-Claude J, Becher H, Blettner M, Qiu S, Yang G, Wahrendorf J. Familial aggregation of oesophageal cancer in a high incidence area in China. Int J Epidemiol. 1997;26(6):1159-65.

18. Mohner M, Wendt A. A diagnostic bias might be a much simpler explanation for the apparently elevated risk for nasopharyngeal cancer with respect to formaldehyde. J Occup Med Toxicol. 2016;11:3.

19. Romaniuk A, Lyndin M, Sikora V, Lyndina Y, Romaniuk S, Sikora K. Heavy metals effect on breast cancer progression. J Occup Med Toxicol. 2017;12:9.

20. Castro C, Peleteiro B, Lunet N. Modifiable factors and esophageal cancer: a systematic review of published meta-analyses. J Gastroenterol. 2017:53(1):37-51.

21. Budnik LT, Baur X, Harth V, Hahn A. Alternative drugs go global: possible lead and/or mercury intoxication from imported natural health products and a need for scientifically evaluated poisoning monitoring from environmental exposures. J Occup Med Toxicol. 2016:11:6.

22. Groneberg-Kloft B, Fischer TC, Quarcoo D, Scutaru C. New quality and quantity indices in science (NewQIS): the study protocol of an international project. J Occup Med Toxicol. 2009;4:16.

23. van Eck NJ, Waltman L. Citation-based clustering of publications using CitNetExplorer and VOSviewer. Scientometrics. 2017;111(2):1053-70.
24. NLM, MeSH. https://www.ncbi.nlm.nih.gov/mesh/?term=cance r\%2C+esophageal (2017). Accessed Apr 2017.

25. Hirsch JE. Does the $\mathrm{H}$ index have predictive power? Proc Natl Acad Sci USA. 2007;104(49):19193-8.

26. OECD. OECD Data, research and development statistics (RDS). http:// www.oecd.org/innovation/inno/researchanddevelopmentstatisticsrds htm (2018). Accessed May 2018.

27. WHO. Globocan 2012, estimated cancer incidence, mortality and prevalence worldwide in 2012. http://globocan.iarc.fr/Pages/summary table _pop_sel.aspx (2012). Accessed July 2018.

28. Gastner MT, Newman ME. From the cover: diffusion-based method for producing density-equalizing maps. Proc Natl Acad Sci USA 2004;101(20):7499-504.

29. Lopez-Illescas C, Anegon FD, Moed HF. Comparing bibliometric countryby-country rankings derived from the Web of Science and Scopus: the effect of poorly cited journals in oncology. J Inf Sci. 2009;35(2):244-56.

30. Kulkarni AV, Aziz B, Shams I, Busse JW. Comparisons of citations in Web of Science, Scopus, and Google Scholar for articles published in general medical journals. JAMA. 2009;302(10):1092-6.

31. Aksnes DW. A macro study of self-citation. Scientometrics. 2003;56(2):235-46.

32. Baldi S. Normative versus social constructivist processes in the allocation of citations: a network-analytic model. Am Sociol Rev. 1998;63(6):829-46.

33. Noorden V. Global scientific output doubles every nine years. http://blogs .nature.com/news/2014/05/global-scientific-output-doubles-every-nineyears.html (2014). Accessed 2017.

34. Devesa SS, Blot WJ, Fraumeni JF Jr. Changing patterns in the incidence of esophageal and gastric carcinoma in the United States. Cancer. 1998:83(10):2049-53.

35. Bang YJ, Van Cutsem E, Feyereislova A, Chung HC, Shen L, Sawaki A, et al. Trastuzumab in combination with chemotherapy versus chemotherapy alone for treatment of HER2-positive advanced gastric or gastrooesophageal junction cancer (ToGA): a phase 3, open-label, randomised controlled trial. Lancet. 2010;376(9742):687-97.

36. Herskovic A, Martz K, Al-Sarraf M, Leichman L, Brindle J, Vaitkevicius V, et al. Combined chemotherapy and radiotherapy compared with radiotherapy alone in patients with cancer of the esophagus. N Engl J Med. 1992;326(24):1593-8

37. van Hagen $P$, Hulshof MC, van Lanschot JJ, Steyerberg EW, van Berge Henegouwen MI, Wijnhoven BP, et al. Preoperative chemoradiotherapy for esophageal or junctional cancer. N Engl J Med. 2012;366(22):2074-84.

38. Chen $\mathrm{W}$, Zheng $\mathrm{R}$, Zeng $\mathrm{H}$, Zhang $\mathrm{S}$. The updated incidences and mortalities of major cancers in China, 2011. Chin J Cancer. 2015;34(11):502-7.

39. Global Burden of Disease Cancer C, Fitzmaurice C, Dicker D, Pain A, Hamavid H, Moradi-Lakeh M, et al. The global burden of cancer 2013. JAMA Oncol. 2015:1(4):505-27.

40. Song H, Zhu JW, Lu DH, Fang F, Ye WM, Lundell L, et al. Psychiatric morbidity and its impact on surgical outcomes for esophageal and gastric cancer patients: a nationwide cohort study. Oncotarget 2017;8(46):81305-14.

41. Xie SH, Wahlin K, Lagergren J. Cause of death in patients diagnosed with esophageal cancer in Sweden: a population-based study. Oncotarget. 2017:8(31):51800-9.

42. Xie SH, Jernberg T, Mattsson F, Lagergren J. Digitalis use and risk of gastrointestinal cancers: a nationwide population-based cohort study. Oncotarget. 2017:8(21):34727-35.

43. Shibata A, Matsuda T, Ajiki W, Sobue T. Trend in incidence of adenocarcinoma of the esophagus in Japan, 1993-2001. Jpn J Clin Oncol. 2008;38(7):464-8.

44. Man JP, Weinkauf JG, Tsang M, Sin DD. Why do some countries publish more than others? An international comparison of research funding, English proficiency and publication output in highly ranked general medical journals. Eur J Epidemiol. 2004;19(8):811-7.

45. Schmidt S, Bundschuh M, Scutaru C, Klingelhoefer D, Groneberg DA, Gerber A. Hepatitis B: global scientific development from a critical point of view. J Viral Hepatitis. 2014;21(11):786-93.

46. Groneberg DA, Weber E, Gerber A, Fischer A, Klingelhoefer D, Brueggmann D. Density equalizing mapping of the global tuberculosis research architecture. Tuberculosis. 2015;95(4):515-22.

47. Groneberg-Kloft B, Klingelhoefer D, Zitnik SE, Scutaru C. Traffic medicinerelated research: a scientometric analysis. BMC Public Health. 2013;13:13. 
48. Carter AJ, Nguyen CN. A comparison of cancer burden and research spending reveals discrepancies in the distribution of research funding BMC Public Health. 2012;12:526.

49. Carter AJ, Delarosa B, Hur H. An analysis of discrepancies between United Kingdom cancer research funding and societal burden and a comparison to previous and United States values. Health Res Policy Syst. 2015;13:62.

\section{Publisher's Note}

Springer Nature remains neutral with regard to jurisdictional claims in published maps and institutional affiliations.
Ready to submit your research? Choose BMC and benefit from:

- fast, convenient online submission

- thorough peer review by experienced researchers in your field

- rapid publication on acceptance

- support for research data, including large and complex data types

- gold Open Access which fosters wider collaboration and increased citations

- maximum visibility for your research: over $100 \mathrm{M}$ website views per year

At BMC, research is always in progress.

Learn more biomedcentral.com/submissions 